Care: Jurnal Ilmiah Ilmu Kesehatan Vol .7, No.3, 2019, hal 76-83

Tersedia online di https://jurnal.unitri.ac.id/index.php/care

ISSN 2527-8487 (online)

ISSN 2089-4503 (cetak)

\title{
PENGARUH PEMBERIAN JAHE (Zingiber officinale) TERHADAP GLUKOSA DARAH PASIEN DIABETES MELLITUS
}

\author{
Idola Perdana Sulistyoning Suharto ${ }^{1)}$, Erik Irham Lutfi ${ }^{2)}$, Mega Diasty Rahayu ${ }^{3)}$ \\ ${ }^{1), 2,3)}$ Fakultas Ilmu Kesehatan Universitas Kadiri \\ E-mail : idolaperdana@gmail.com
}

\begin{abstract}
Diabetes mellitus is a group of metabolic diseases characterized by byperglycemia (increased blood glucose levels) that affects abnormal insulin secretion, insulin action, or maybe both. The objective of this study was to analysis effect of giving ginger (Zingiber officinale) to the blood glukose in patients of diabetes mellitus. The method was one group pretest - posttest design. There were 16patients of diabetes mellituswho was given ginger (Zingiber officinale). Ginger (Zingiber officinale) was given twice a day for a week. The dose of ginger is $50 \mathrm{mg}$ of ginger boiled with $200 \mathrm{ml}$ of water Blood glucose was measured before and after ginger administration. The data was analyzed by wilcoxon signed rank test. Based on wilcoxon signed rank test, obtained result that there was a significant difference $(a<0.05)$ of blood glucose before and after giving ginger (Zingiber officinale) with $p$ value $=0.000$.The conclusion of this study was there were differences in blood glucose levels before and after ginger (Zingiber officinale) therapy was given in patients with Diabetes Mellitus.
\end{abstract}

Keywords : Ginger (Zingiber officinale); blood glucose; diabetes mellitus.

\begin{abstract}
ABSTRAK
Diabetes Mellitus adalahsekelompok penyakit metabolik yangdicirikan dengan adanya kondisi hiperglikemia(peningkatan level glukosa darah) yang dikarenakan adanya kelainan dalam hal sekresi insulin, kelainan kerja dari insulin atau mungkin bisa keduanya.Penelitian ini bertujuan untuk menganalisis efek pemberian jahe (Zingiber officinale) terhadap glukosa darah pasien diabetes mellitus. Pendekatan digunakan adalah one group pretest - posttest design. Terdapat 16pasien diabetes mellitus yang diberikan jahe (Zingiber officinale). Jahe diberikan dua kali sehari selama seminggu. Dosis pemberian jahe yaitu $50 \mathrm{mg}$ jahe direbus dengan $200 \mathrm{ml}$ air. Data dianalisis menggunakan uji wilcoxon signed rank. Berdasarkan hasil yang diperoleh dari uji wilcoxon signed rank didapatkan perbedaan yang signifikan) kadar glukosa darah antara sebelum dan setelah pemberian jahe (Zingiber officinale) dengan $(\alpha<0,05$ dan $\mathrm{p}$-value $=0,000$. Kesimpulan yang dapat diperoleh adalah terdapat perbedaan kadar glukosa darah sebelum dan sesudah pemberian jahe pada pasien diabetes mellitus.
\end{abstract}

Kata Kunci : Jahe (Zingiber officinale); glukosa darah; diabetes mellitus.

Cara mengutip: Suharto, Idola P. Sulistyoning., Lutfi, E. Irham, \& Rahayu, Mega D. (2019). Pengaruh Pemberian Jahe (Zingiber officinale) terhadap Glukosa Darah Pasien Diabetes Mellitus. Care:Jurnal Ilmiah Ilmu Kesehatan, 7(3), 76-83 


\section{PENDAHULUAN}

Diabetes Mellitus adalah sekelompok penyakit metabolik yang dicirikan dengan adanya kondisi hiperglikemia(peningkatan level glukosa darah) yang dikarenakan adanya kelainan dalam hal sekresi insulin, kelainan kerja dari insulin atau mungkin bisa keduanya (Muntafiah, Yulianti, Cahyaningtyas, \& Ismi, 2017). Diabetes mellitus merupakan penyakit/kelainan yang kasusnya cukup tinggi di dunia. Terdapat 382 juta kasus diabetes pada tahun 2013 dan bisa jadi meningkat menjadi 471 juta kasus yang mungkin akan ditemukan pada tahun 2035

Data dari WHO, pada tahun 2010 Indonesia berada di urutan empat kategori penderita DM tertinggi di dunia, yaitu 8,4 juta kasus dan diprediksiterus meningkat ke- 21,3 juta kasusdi tahun 2030. Berdasarkan RISKESDAS 2018, jumlah penderita DM yang berumur diatas 15 tahun sebanyak 2,6\% dari jumlah penduduk Jawa Timur(Arman, Almasdy, \& Martini, 2016).

Federasi Diabetes Internasional (FDI) Atlas tahun 2017 edisi delapan menjelaskan jumlah pasien diabetes di Indonesia sudah mencapai 10,3 juta kasus. Jumlah itu mungkin akan meningkat mencapai 16,7 juta kasus pada 2045. Berdasarkan data Riskesdas, Indonesia ditemukan 10 juta kasus, dan 17,9 juta penduduk yang beresiko diabetes. Jawa Timur masuk dalam 10 besar penderita DM se-Indonesia atau berada pada peringkat Sembilan (Marine \& Adiningsih, 2015).

Berdasarkan laporan di Dinas Kesehatan Kota Kediri prevalensi penderita diabetes mellitus sebanyak 7789 kasus dan penderita diabetes mellitus Di Puskesmas Sukorame sebanyak 1771 kasus pada tahun 2015.

Faktor yang berpengaruh pada kasus Diabetes Mellitus terbagi menjadi 2 macam yaitu faktor internal dan eksternal. Faktor internal itu sendiri adalah faktor keturunan. Sedangkan faktor eksternalnya antara lain adalah kegemukan atau obesitas, pola makan yang salah, minum obat yang bisa menaikkan kadar gula darah, proses menua, stress pola tidur dan aktifitasfisik yang kurang (DEWI, 2013).

Komplikasi DM digolongkan menjadi komplikasi akut dan kronis. Komplikasi akut merupakan komplikasi jangka pendek akibat ketidakseimbangan glukosa yang meliputi hipoglikemia, ketoasidosis diabetik (DKA), sindrom hiperglikemik hiperosmolar non ketotik (NHNK). Komplikasi/dampak kronis biasanya terjadi setelah 10-15 tahun meliputi komplikasi makrovaskular, komplikasi mikrovaskular dan penyakit neuropati. Komplikasi makrovaskular yaitu mengenai 
pembuluh darah koroner, pembuluh darah perifer dan pembuluh darah serebral sedangkan komplikasi mikrovaskular: mengenai mata(retinopati) dan juga ginjal(neuropati) (Hati, Setiawan, \& Yuliarta, 2013).

Pengobatan Diabetes Mellitus dapat dilakukan dengan menggunakan pengobatan farmakologi dan non farmakologi, tindakan farmakologi bukan merupakan suatu tindakan mandiri perawat melainkan suatu tindakan kolaborasi dengan tindakan medis lain. Salah satu dari pengobatan farmakologi yang sering digunakan adalah menggunakan terapi insulin, baik yang berbentuk oral maupun yang memerlukan suntikan dengan dosis ringan sampai dosis berat. Akan tetapi efek samping dari terapi obat ini banyak dialami pasien seperti hipoglikemia, peningkatan berat badan, dan gangguan saluran cerna. Kondisi tersebut mendorong eksplorasi bahan alam sebagai sumber pengobatan alternatif untuk terapi DM(Supit, Massi, \& Kallo, 2018).

Saat ini pengobatan herbal sudah banyak digunakan secara luas meskipun komponen zat/bahan aktif yang berkasiat belum diketahui secara pasti.WHO telah memberi ijin dalam hal penggunaan tanaman obat/herbal untuk beragam penyakit, termasuk DM. Contoh dari tanaman obat yang ada di masyarakat adalah jahe.
Salah satu jenis tanaman obat di Indonesia adalah jahe (Zingiber officinale Roscoe). Jahe memiliki kandungan zat/bahan aktif yaitu flavonoid,gingerol, shogaol dan oleoresin (Sulistyoningsih, Rakhmawati, \& Septiyanto, 2018). Gingerol dan shogaol adalah komponen fenol yang memiliki efek antiinflamasi, antikanker, dan antitumor (Etika, Nurrahayu, \& SS, 2017).

Jahe memiliki berbagai manfaat terutama bagi kesehatan. Kandungan fenolik membuat tanaman ini memiliki kemampuan untuk menurunkan glukosa darah bagi penderita diabetes mellitus. Penggunaan jahe sebagai obat dirasa sangat bergunat karena mudah ditemukan, praktis, dan ekonomis (Wicaksono, 2015).

Penelitian Al Amin et al.mempelajari kemampuan hipoglikemik oleh jahe dengan sample yang digunakan adalah pada tikus yang terlebih dahulu diinduksi diabetes. Tikus diberikan jahe kondisi segar sebanyak $500 \mathrm{mg} / \mathrm{kg}$ setiap hari selama 7 minggu. Berdasarkan penelitian, didapatkan hasil bahwa dosis ini signifikan dan efektif untuk menurunkan kadar serum triasilgliserol,kolesterol, danglukosa. Singh et al. pernah melakukan studi tentang pengaruh/efek jahe sebagai zat antiglikemik, menurunkan kadar lemak darah dan juga sebagai agen antioksidan untuk diabetes tipe2(Putra, Aulia, \& Wahyuni, 2017). Oleh karena tingginya 
potensi jahe, peneliti ingin melakukan penelitian mengenai "Efek Pemberian Jahe Terhadap Kadar Glukosa Darah Pasien Diabetes Mellitus".

\section{METODE PENELITIAN}

Sampel penelitian adalah keseluruhan objek penderita Diabetes Mellitus yang tidak menggunakan insulin ataupun sudah lama tidak menggunakan insulin sebanyak 16 sampel. Teknik pengambilan sempel yang digunakan adalah metode total sampling yaitu dengan cara pengambilan sampel pada semua populasi.

Peneliti menggunakan alat ukur glukotest dan lembar observasi untuk mengukur kadar gula darah. Bahan yang digunakan untuk penelitian ini adalah air rebusan jahe, gelas, glukotest dan data calon responden penderita Diabetes Mellitus di Kelurahan Sukorame Kota Kediri. Rebusan jahe dibuat dengan cara memasukkan $50 \mathrm{mg}$ jahe ke dalam $200 \mathrm{~mL}$ air, direbus hingga volume air menjadi $100 \mathrm{~mL}$. Penelitian ini menggunakan pendekatan the one group pretest - posttest design. Variabel bebas dalam penelitian ini adalah pemberian jahe dan variabel terikatnya adalah glukosa darah.

Pada pengambiln data, diawali dengan permohonan ijin penelitian dari Institusi Fakultas Ilmu Kesehatan Universitas Kadiri yang disampaikan kepada DPM
Kota Kediri, dan Dinas Kesehatan Kota Kediri. Selang 2 mingguan dari pengajuan surat ke DPM, ada surat balasan yang ditujukan ke Dinas Kesehatan Kota Kediri. Cara pengambilan data meliputi :

1. Membuat surat survei.

2. Mencari data calon responden.

3. Melakukan pendekatan dan menjelaskan calon responden, kemudian meminta responden mengisi surat persetujuan.

4. Responden diberi penjelasan tentang maksud, tujuan, dan manfaat penelitian yang akan diakukan.

5. Setelah responden memahami maksud dan tujuan penelitian, responden diminta menandatangangani lembar persetujuan untuk menjadi responden.

6. Peneliti melakukan pre tess dengan cara mengukur glukosa darah sebelum diberikan jahe.

7. Peneliti membagikan rebusan jahe yang sudah di siapkan.

8. Setelah dibagikan semua selanjutnya di minta minum sesuai aturan.

9. Setelah selesai (hari ke 7), peneliti melakukan posttest dengan cara memeriksa kembali kadar glukosa darah.

10. Setelah semua data terkumpul kemudian dilakukan pengolahan dan analisi data. 
HASIL

Tabel 1. Distribusi frekuensi usia responden

\begin{tabular}{lcc}
\hline \multicolumn{1}{c}{ Usia } & $\mathbf{f}$ & $\mathbf{( \% )}$ \\
\hline $20-34$ tahun & 5 & 31,25 \\
$35-44$ tahun & 11 & 68,75 \\
$45-54$ tahun & 4 & 25 \\
$55-59$ tahun & 3 & 18,75 \\
$\geq 60$ tahun & 6 & 37,5 \\
\hline Total & 16 & 100 \\
\hline
\end{tabular}

Berdasarkan Tabel 1 dapat diketahui sebagian besar responden (68,75\%) yaitu 11 responden berumur 35 - 44 tahun.

Tabel 2. Distribusi frekuensi jenis kelamin responden

\begin{tabular}{lcc}
\hline \multicolumn{1}{c}{ Jenis Kelamin } & f & $\mathbf{( \% )}$ \\
\hline Laki-laki & 1 & 6,25 \\
Perempuan & 15 & 93,75 \\
\hline Total & 16 & 100 \\
\hline
\end{tabular}

Berdasarkan Tabel2 dapat dilihat bahwa hampir seluruh responden( $93,75 \%)$ yaitu 15 responden berjenis kelamin perempuan

Tabel 3 Rerata glukosa darah sebelum diberikan terapi jahe

\begin{tabular}{ccc}
\hline Total & $\begin{array}{c}\text { Rerata kadar } \\
\text { glukosa darah }\end{array}$ & $\begin{array}{c}\text { Standar } \\
\text { Deviasi }\end{array}$ \\
\hline $\mathbf{1 6}$ & 270,50 & 52,604 \\
\hline
\end{tabular}

Berdasarkan tabel3 dapat diketahui bahwa rerata glukosa darah sebelum diberikan terapi jahe adalah 270,50.

Tabel 4. Rerata glukosa darah sesudah diberikan terapi jahe

\begin{tabular}{ccc}
\hline Total & $\begin{array}{c}\text { Rerata kadar } \\
\text { glukosa darah }\end{array}$ & $\begin{array}{c}\text { Standar } \\
\text { Deviasi }\end{array}$ \\
\hline $\mathbf{1 6}$ & 222,75 & 51,750 \\
\hline
\end{tabular}

Berdasarkan Tabel 4 dapat diketahui bahwa rerata glukosa darah sesudah diberikan terapi jahe adalah 222,75

Tabel 5. Hasil uji wilcoxon signed rank glukosa darah sebelum dan sesudah diberikan terapi jahe

\begin{tabular}{ccc}
\hline Total & Signifikansi & Alfa \\
\hline $\mathbf{1 6}$ & 0,000 & 0,05 \\
\hline
\end{tabular}

Berdasarkan Tabel 5 dapat diketahui bahwa nilai $\alpha 0,05$ dan nilai signifikansi 0,000 sehingga dapat diartikan bahwa terdapat perbedaan kadar glukosa darah sebelum dan setelah diberikan terapi jahe

\section{PEMBAHASAN}

Berdasarkan Tabel 3 dapat diketahui bahwa rerata kadar glukosa darah sebelum diberikan terapi jahe adalah 270,50 dan berdasarkan tabel 4 rerata kadar glukosa darah sesudah diberikan terapi jahe adalah 222,75. Kedua tabel tersebut menunjukkan bahwa terdapat penurunan kadar glukosa darah sebelum diberikan terapi jahe dan sesudah pemberian terapi jahe.

Jahe mempunyai kandungan bahan aktif untuk menurunkan kadar glukosa darah. Bahan aktif tersebut adalah gingerol dan shogaol. Kedua bahan aktif tersebut merupakan turunan dari senyawa flavonoid dan fenol yang berfungsi sebagai antidiabetes(Yanto, Mahmudati, \& Susetyorini, 2016) Dengan adanya efek antidiabetes, maka pemberian jahe pada 
pasien dengan diabetes mellitus akan menurunkan kondisi hiperglikemia dengan jalan menurunkan kadar glukosa plasma pada pasien.

Pada penelitian yang pernah dilakukan sebelumnya didapatkan adanya penurunan kadar glukosa darah yang signifikan melalui pemberian jus jahe (Zingiber officinale) pada kelompok diabet dan nondiabet. Aktivitas antidiabetes Zingiber officinale berhubungan melalui 5-HT antagonisme (reseptor kimia 6-gingerol dan zat penanda biologis yang ada di Zingiber officinale). Hasil penelitian menunjukkan aktivitas antagonis 5-HT saat ini untuk efek metanol dan kelompoknya pada tikus NIDDM yang telah diinduksi oleh STZ dan berhubungan dengan konsentrasi 6gingerol yang ada di dalamnya. Hasil penelitian tersebut menunjukkan 6-gingerol menyebabkan hipoglikemia saat diberikan pada tikus diabetes (Zahrotin, 2018).

Jahe tidak hanya berfungsi sebagai agen antidiabetes yang memiliki sifat insulinotropika, jahe juga berfungsi sebagai agen antioksidan. Kandungan jahe yaitu senyawa fenol yang mengandung zingeron, gingerol, danshogaol, memiliki efek antioksidan(Hernani \& Winarti, 2012)(S.S, Nurrahayu, \& Etika, 2017). Penelitian mengenai jahe dengan sifat antioksidannya adalah penelitian yang dilakukan pada tikus yang sebelumnya diinduksi dengan STZ dimana STZ ini akan membuat kadar antioksidan menjadi turun, kemudian dengan adanya pemberian diet jahe didapatkan bahwa kadar antioksidan meningkat secara signifikan (Sajid, Akash, Rehman, \& Tariq, 2015).

Antioksidan berfungsi untuk meredam kerusakan oksidatif dikarenakan kondisi hiperglikemia. Hiperglikemia terlibat pada proses terbentuknya radikal bebas. Naiknya kadar antioksidan yang cukup dapatmencegah terjadinya komplikasi klinis pada DM, yaitu diantaranya dapat menghambat komplikasi mikrovaskular, penurunan angka kejadian jantung koroner, perbaikan pada sistem saraf otonom di jantung, dan vasodilatasi pembuluh darah (Setiawan \& Suhartono, 2005).

Berdasarkan hasil uji wilcoxon signed rank pada tabel 6 didapatkan bahwa nilai signifikansi adalah 0,000 dan nilai $\alpha$ adalah 0,05 sehingga terdapat perbedaan kadar glukosadarah sebelum dan sesudah diberikan terapi jahe. Penurunan ini menunjukkan pemberian jahe menurunkan kadar glukosa darah.

\section{KESIMPULAN}

Rerata kadar glukosa darah sebelum pemberian terapi jahe adalah 270,5. Rerata kadar glukosa darah setelah pemberian terapi jahe adalah 222,75. Terdapat perbedaan kadar glukosa darah sebelum 
dan sesudah diberikan terapi jahe pada pasien Diabetes Mellitus.

\section{UCAPAN TERIMAKASIH}

Alhamdulillah, puji syukur kehadirat Alloh SWT yang Maha Pengasih lagi Maha Penyayang atas rahmat dan karuniaNya sehingga peneliti dapat menyelesaikan penelitian ini dengan tepat waktu. Terima kasih saya ucapkan kepada Fakultas Ilmu Kesehatan Universitas Kadiri dan LP3M Universitas Kadiri yang telah membantu memberikan dana pada penelitian ini serta kepada Universitas Tribhuwana Tunggadewi yang telah menerbitkan penelitian ini melalui jurnal keperawatannya yaitu "Care".

\section{REFERENSI}

Arman, E., Almasdy, D., \& Martini, R. D. (2016). Pengaruh Pemberian Serbuk Kering Jahe Merah Terhadap Pasien Diabetes Melitus Tipe 2 Pendahuluan Diabetes Melitus ( DM ) merupakan suatu kelompok penyakit metabolik dengan karakteristik hiperglikemia yang terjadi karena kelainan sekresi insulin, kelainan. Jurnal Ipteks Terapan, 10(3), 161-169.

Dewi, R. P. (2013). Faktor Risiko Perilaku Yang Berhubungan Dengan Kadar Guladarah Pada Penderita Diabetes Melitus Tipe 2 Di Rsud Kabupaten Karanganyar. Universitas Diponegoro.

Etika, A. N., Nurrahayu, K. I., \& SS, I. P. (2017). Pengaruh Ekstrak Jahe ( Zingiber Officinale Roscoe ) Terhadap Jumlah Sel Fibroblas Pada Tikus( Rattus Norvegicus ). Journal of
Nursing Care \& Biomolecular, 2(1), 10 14.

Hati, K., Setiawan, M., \& Yuliarta, D. (2013). Pengaruh Rebusan Daun Sirih Merah ( Piper Crocatum ) Terhadap. Saintika Medika, 9(1), 59-64.

Hernani, \& Winarti, C. (2012). Kandungan Bahan Aktif Jahe Dan Pemanfa Atannya Dalam Bidang Kesehatan. InBalai Besar Penelitian dan Pengembangan Pascapanen Pertanian (pp. 125-142).

Marine, D., \& Adiningsih, S. (2015). Perbedaan Pola Konsumsi Dan Status Gizi Antara Remaja Dengan Orang Tua Diabetes Melitus ( DM ) Dan Non DM. Media Giži Indonesia, 10(2), 179-183.

Muntafiah, A., Yulianti, D., Cahyaningtyas, H. A., \& Ismi, H. D. (2017). Madu Terhadap Kadar Kolesterol Total Tikus Model Diabetes Melitus. Scripta Biologica, 4(1), 4-6.

Putra, A. M. P., Aulia, D., \& Wahyuni, A. (2017). Uji Aktivitas Ekstrak Etanol Daun Belimbing Wuluh ( Averrhoa Bilimbbi L .) Terhadap Penurunan Kadar Glukosa Darah Mencit Putih Jantan Yang Diinduksi Aloksan. Jurnal Ilmiah Ibnu Sina, 2(2), 263-269.

S.S, I. P., Nurrahayu, K. I., \& Etika, A. N. (2017). The Effect of Ginger ( Zingiber Officinale Roscoe ) Extract to the Number of Neutrophil Cell in Incision Wound of White Rats ( Rattus Norvegicus ). In Advances in Health Sciences Research (Vol. 2, pp. 381-385). Atlantis Press.

Sajid, M., Akash, H., Rehman, K., \& Tariq, M. (2015). Zingiber officinale and Type 2 Diabetes Mellitus : Evidence from Experimental Zingiber officinale and type 2 diabetes mellitus : Evidences from experimental studies. Researchgate, (March). https://doi.org/10.1615/CritRevEuk aryotGeneExpr.2015013358

Setiawan, B., \& Suhartono, E. (2005). Stres 
Oksidatif dan Peran Antioksidan pada Diabetes Melitus. Majalah Kedokteran Indonesia, 86-91.

Sulistyoningsih, M., Rakhmawati, R., \& Septiyanto, A. A. (2018). Pengaruh Pemberian Jahe, Kunyit dan Salam Terhadap Kadar Asam Urat dan Glukosa Darah pada Bebek. Jurnal Peternakan Indonesia, 20(2), 78-83.

Supit, J., Massi, G., \& Kallo, V. (2018). Efektifitas Pemberian Edukasi Dengan Metode Video Dan Focus Group Discussion ( Fgd ) Terhadap Tingkat Pengetahuan Pasien Dm Tipe 2 Di Klinikdiabetes Kimia Farma Husada Manado. E-Journal Keperawatan (e-Kep, 6(1), 1-6.

Wicaksono, A. P. (2015). Pengaruh Pemberian Ekstrak Jahe Merah ( Zingiber Officinale ) terhadap Kadar Glukosa Darah Puasa dan Postprandial pada Tikus Diabetes. Majority, 4(7), 97-102.

Yanto, A. R., Mahmudati, N., \& Susetyorini, R. E. (2016). Seduhan Jahe (Zingiber Officinale Rosce. ) Dalam Menurunkan Kadar Glukosa Darah Tikus Model Diabetes Tipe-2 (Niddm) Sebagai Sumber Belajar Biologi. Jurnal Pendidikan Biologi Indonesia, 2(3), 258-264.

Zahrotin, A. (2018). Pengaruh Insulin , Jahe Dan Kombinasi Keduanya Terhadap Jumlah Sel Trofoblas Rattus Norvegicus Model. Qanun Medika, 2(1), 21-28. 